\title{
Interactions of Soil Order and Land Use Management on Soil Properties in the Kukart Watershed, Kyrgyzstan
}

\author{
Zulfiia Sakbaeva, ${ }^{1}$ Veronica Acosta-Martínez, ${ }^{2}$ Jennifer Moore-Kucera, ${ }^{3}$ \\ Wayne Hudnall, ${ }^{3}$ and Karabaev Nuridin ${ }^{4}$ \\ ${ }^{1}$ Department of Ecology and Natural Resources, Jalal-Abad State University, 57 Lenin Street, \\ 715600 Jalal-Abad, Kyrgyzstan \\ ${ }^{2}$ Cropping Systems Research Laboratory, United States Department of Agriculture-Agricultural Research Service, \\ 3810 4th Street, Lubbock, TX 79415, USA \\ ${ }^{3}$ Department of Plant and Soil Science, Texas Tech University, 15th and Detroit, Room 201, Mail Stop 2122, \\ Lubbock, TX 79409-2122, USA \\ ${ }^{4}$ Department of Soil Science, Agrochemistry and Farming, Kyrgyz National Agrarian University, \\ 68 Mederov Street, 720005 Bishkek, Kyrgyzstan \\ Correspondence should be addressed to Jennifer Moore-Kucera, jennifer.moore-kucera@ttu.edu
}

Received 24 May 2012; Revised 17 July 2012; Accepted 30 July 2012

Academic Editor: D. L. Jones

Copyright () 2012 Zulfiia Sakbaeva et al. This is an open access article distributed under the Creative Commons Attribution License, which permits unrestricted use, distribution, and reproduction in any medium, provided the original work is properly cited.

Surveys of soil properties related to soil functioning for many regions of Kyrgyzstan are limited. This study established ranges of chemical (soil organic matter (SOM), $\mathrm{pH}$ and total $\mathrm{N}(\mathrm{TN})$ ), physical (soil texture), and biochemical (six enzyme activities of C, N, P, and S cycling) characteristics for nine profiles from the Kukart watershed of Jalal-Abad region in Kyrgyzstan. These profiles represent different soil orders (Inceptisols, Alfisols, and Mollisols) and land uses (cultivated, nut-fruit forests, and pasture). The Sierozem (Inceptisols) soils had the highest $\mathrm{pH}$ and contained the lowest SOM and TN contents compared to the Brown, Black-brown, and Meadow-steppe soils (Alfisols and Mollisols). Enzymatic activities within surface horizons $(0-18 \mathrm{~cm})$ typically decreased in the following order: forest $>$ pasture > cultivated. Enzyme activity trends due to land use were present regardless of elevation, climate, and soil types although subtle differences among soil types within land use were observed. The significant reductions in measured soil enzyme activities involved in $\mathrm{C}, \mathrm{N}, \mathrm{P}$, and $\mathrm{S}$ nutrient transformations under cultivation compared to pasture and forest ecosystems and lower values under Inceptisols can serve as soil quality indicators for land use decisions in the watershed.

\section{Introduction}

Expected changes in global climate, land uses, population distribution, and water availability create challenges to meet societal needs for ecosystem services that agricultural, forestry, and pasture lands provide. In order to make sound decisions regarding land use, knowledge of specific properties related to soil functioning under different land use scenarios are necessary. Dynamic properties such as enzyme activities and soil organic matter (SOM) are sensitive to land management practices and can provide valuable information about important soil processes such as nutrient cycling, decomposition and formation of SOM, and overall productivity potential. Enzymatic potential in soils is influenced by inherent soil properties such as soil texture, type of clay, and drainage class that were established as soil formed as well as dynamic properties such as SOM, $\mathrm{pH}$, and nutrient holding capacity. Among the various enzymes present in soil, assessment of the activities of hydrolases involved in $\mathrm{C}, \mathrm{N}, \mathrm{P}$, and $\mathrm{S}$ cycling can provide information about soil fertility $[1,2]$ as well as the metabolic potential of soil $[3,4]$. Previous studies with soils from various regions have shown that enzyme activities are sensitive to soil changes due to tillage $[5,6]$, cropping systems [7-9], and land use [10-12]. 
Surveys of soil properties related to soil functioning for many regions of Kyrgyzstan are limited. Kyrgyzstan is a mountainous country located in the north-eastern part of Central Asia. Altitudes range from 500 to $5000 \mathrm{~m}$ above sea level creating diverse ecological landscapes. The land area of the Kyrgyzstan represents $191,800 \mathrm{~km}^{2}$ with approximately 5.0\% under forest, $7.0 \%$ under arable and permanent crops, and 49\% are pastures [13]. Many forested regions within this country contain the original genetic sources of many domesticated fruit and nut trees that are cultivated widely in temperate countries. For example, KaraAlma and Arslanbob in the Jalal-Abad Province are home to some of the largest walnut forests, where trees occur in extensive, nearly pure stands at 1,000-2,000 $\mathrm{m}$ altitude [14]. In this country, there are soil studies that date to $>40$ years ago about SOM [15], the activities of urea and phosphatases [16] and microbial classification using culture methods [17], however, few current soil evaluations exist. Information about soil properties for this region will increase the knowledge base regarding how typical land uses in the region impact the functionality of the soil ecosystem. The objective of this study, therefore, was to evaluate selected chemical (SOM, pH, and total $\mathrm{N}$ ), physical (soil texture), and biochemical (enzyme activities involved in C, N, P, and $S$ cycling) characteristics for different soil profiles from the Kukart watershed of the Jalal-Abad region of Kyrgyzstan representing three land uses: cultivated, nut-fruit forests, and pasture.

\section{Material and Methods}

2.1. Geographic Characterization of the Kukart Watershed. The Kukart watershed is located in the Jalal-Abad region of Kyrgyzstan. This region is characterized by a diverse ecological setting (elevation ranging from 500 to $2000 \mathrm{~m}$, fluctuating weather patterns and soil types), which supports multiple land use options important for the region's economy (i.e., agricultural, grazing lands, nut-fruit forests, etc.). A total of nine soil profiles were sampled from three contrasting land uses within the Kukart watershed $\left(1370 \mathrm{~km}^{2}\right)$, spanning an elevation gradient from $732 \mathrm{~m}$ to $1942 \mathrm{~m}$ (Table 1 and Figure 1). The Kukart watershed is bordered by latitudes $41^{\circ} 08^{\prime} 10.18^{\prime \prime} \mathrm{N}$ and $40^{\circ} 53^{\prime} 59.2^{\prime \prime} \mathrm{N}$ to the north and south, respectively, and longitudes $72^{\circ} 55^{\prime} 06.99^{\prime \prime} \mathrm{E}$ and $73^{\circ} 34^{\prime} 35.30^{\prime \prime} \mathrm{E}$ to the west and east, respectively. It is located on the western and southwestern slopes of the Fergana and Chatkal ridges of the southwestern Tien-Shan mountain range.

The Kukart watershed is characterized by a continental subtropical climate. In the foothills, the average daily temperature in July is $28^{\circ} \mathrm{C}$. In January daily averages are as low as $-14^{\circ} \mathrm{C}$ (Jalal-Abad Meteorological Station). Conditions are much colder at high elevations, where the average daily temperature for July is $5^{\circ} \mathrm{C}$ and in January is $-28^{\circ} \mathrm{C}$ (Jergetal Meterological Station). The majority of the annual precipitation falls during winter and spring with little precipitation occurring during summer months. Average annual precipitation is between 100 and $500 \mathrm{~mm}$ in the

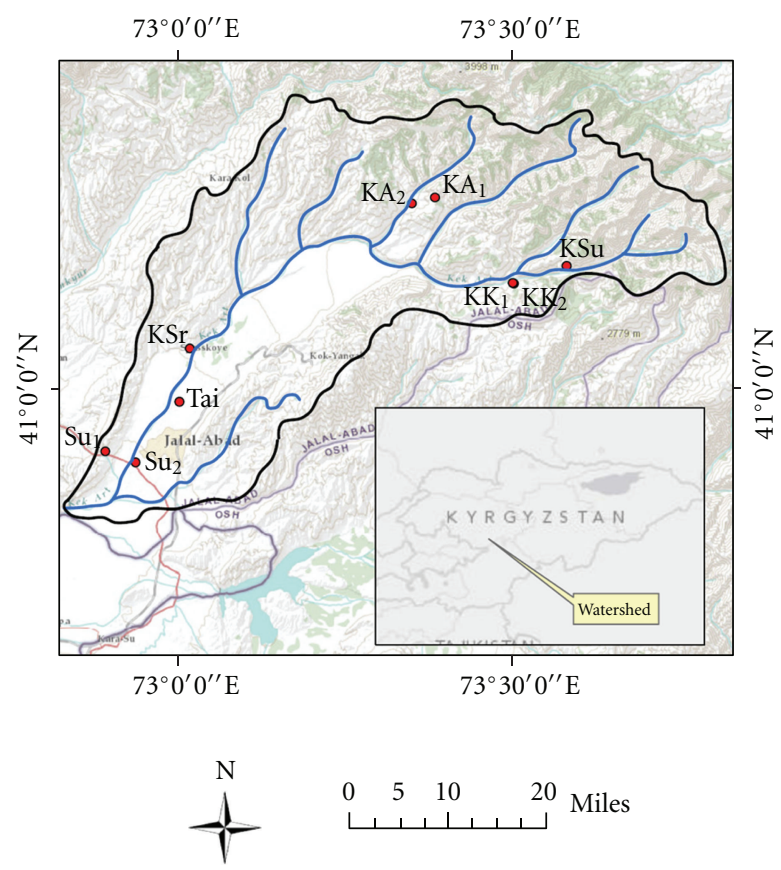

Figure 1: Map showing the Kukart watershed region near JalalAbad, Kyrgyzstan where nine soil profiles were characterized for chemical and physical properties and enzymatic activities. See Table 1 for site location details. Briefly, one forested sites is located in Suzak and the other two are in Kara-Alma and indicated on the map as $\mathrm{Su}_{1}, \mathrm{KA}_{1}$, and $\mathrm{KA}_{2}$, respectively. The pasture sites are located in Kyzyl-Senir (KSr), Kalmak Kyrchyn ( $\left.\mathrm{KK}_{1}\right)$, and Kyzyl-Suu (KSu). The cultivated sites are located in Suzak $\left(\mathrm{Su}_{2}\right)$, Taigara (Tai), and Kalmak-Kyrchyn $\left(\mathrm{KK}_{2}\right)$.

foothills and from 500 to $1,000 \mathrm{~mm}$ in the mountains (above $1,000 \mathrm{~m})$.

The geology of the Kukart watershed is dominated by deposits from the middle and upper Paleozoic period, which was described in detail by Roichenko [18]. In this watershed, clay and clay-siliceous shales and small-grained sandstones are dominant and are up to $150 \mathrm{~m}$ thick. Thick dark greenishgray clay and clay-siliceous, chlorite shales, containing layers of sandstone, diabase, and dolomite limestone were found in the upper part. Main facies types of Devonian deposits for Kukart watershed are effervescent (i.e., carbonates present).

2.2. Soil and Flora Characteristics of Each Land Use Group. For each of the three land use groups, three soil profiles were characterized (Table 1). The first land use group was forests (nut or nut-fruits) with a profile sampled under a pistachio (Pistacia vera L.) plantation located at $850 \mathrm{~m}$ elevation and two profiles sampled under native walnut-fruit forests located at $1580 \mathrm{~m}$ and $1800 \mathrm{~m}$ elevation, respectively, (Figures 2(a)-2(c)). Soils from the two walnut-fruit forests were Black-brown or Brown soils (both Mollisols) while the pistachio plantation was sampled from a Sierozem (Inceptisol). The native walnut (Juglans regia L.) fruit forests also contained Kirghiz apple (Malus kirghisorum Theodet. Fed.), Niedzwetzky apple (Malus niedzwetzkyana Dick.), almond 
TABLE 1: General geographic description and soil classification from each land use site within the Kukart watershed, Kyrgyzstan.

\begin{tabular}{|c|c|c|c|c|c|c|c|c|}
\hline \multirow{2}{*}{ Land use } & \multirow{2}{*}{ Site name } & \multirow{2}{*}{$\begin{array}{l}\text { Dominant } \\
\text { vegetation }^{\mathrm{a}}\end{array}$} & \multirow{2}{*}{ Elevation $(\mathrm{m})$} & \multirow{2}{*}{ Latitude/longitude } & \multirow{2}{*}{ Aspect } & \multirow{2}{*}{$\begin{array}{l}\text { Slope } \\
\text { (degrees) }\end{array}$} & \multicolumn{2}{|c|}{ Soil classification system } \\
\hline & & & & & & & USA & Russia \\
\hline \multirow{3}{*}{ Forest } & Suzak $\left(\mathrm{Su}_{1}\right)$ & Pistachio & 853 & $\begin{array}{l}4055^{\prime} 42.63^{\prime \prime} \mathrm{N} \\
72^{\circ} 53^{\prime} 33.10^{\prime \prime} \mathrm{E}\end{array}$ & Northern & 20 & Inceptisol & Sierozem \\
\hline & Kara-Alma $\left(\mathrm{KA}_{1}\right)$ & Walnut & 1580 & $\begin{array}{l}41^{\circ} 12^{\prime} 30.49^{\prime \prime} \mathrm{N} \\
73^{\circ} 20^{\prime} 57.12^{\prime \prime} \mathrm{E}\end{array}$ & Northern & 43 & Mollisol & Brown \\
\hline & Kara-Alma $\left(\mathrm{KA}_{2}\right)$ & Walnut & 1801 & $\begin{array}{l}41^{\circ} 12^{\prime} 54.66^{\prime \prime} \mathrm{N} \\
73^{\circ} 23^{\prime} 00.05^{\prime \prime} \mathrm{E}\end{array}$ & Northern & 28 & Mollisol & $\begin{array}{l}\text { Black- } \\
\text { brown }\end{array}$ \\
\hline \multirow{3}{*}{ Pasture } & Kyzyl-Senir (KSr) & Mixed & 930 & $\begin{array}{l}41^{\circ} 02^{\prime} 41.35^{\prime \prime} \mathrm{N} \\
73^{\circ} 01^{\prime} 05.86^{\prime \prime} \mathrm{E}\end{array}$ & Western & 12 & Inceptisol & $\begin{array}{c}\text { Dark } \\
\text { sierozem }\end{array}$ \\
\hline & $\begin{array}{c}\text { Kalmak Kyrchyn } \\
\left(\mathrm{KK}_{1}\right)\end{array}$ & Mixed & 1634 & $\begin{array}{l}41^{\circ} 07^{\prime} 04.28^{\prime \prime} \mathrm{N} \\
73^{\circ} 30^{\prime} 04.27^{\prime \prime} \mathrm{E}\end{array}$ & Northeast & 45 & Alfisol & Brown \\
\hline & Kyzyl-Suu (KSu) & Mixed & 1942 & $\begin{array}{l}41^{\circ} 08^{\prime} 16.89^{\prime \prime} \mathrm{N} \\
73^{\circ} 34^{\prime} 47.13^{\prime \prime} \mathrm{E}\end{array}$ & Northeast & 45 & Mollisol & $\begin{array}{l}\text { Meadow- } \\
\text { steppe }\end{array}$ \\
\hline \multirow{3}{*}{ Cultivated } & Suzak $\left(\mathrm{Su}_{2}\right)$ & Cotton & 732 & $\begin{array}{l}40^{\circ} 54^{\prime} 58.41^{\prime \prime} \mathrm{N} \\
72^{\circ} 56^{\prime} 15.16^{\prime \prime} \mathrm{E}\end{array}$ & N/A & 0.3 & Inceptisol & Sierozem \\
\hline & Taigara (Tai) & Maize & 833 & $\begin{array}{l}40^{\circ} 59^{\prime} 04.65^{\prime \prime} \mathrm{N} \\
73^{\circ} 00^{\prime} 10.50^{\prime \prime} \mathrm{E}\end{array}$ & N/A & 0.3 & Inceptisol & Sierozem \\
\hline & $\begin{array}{c}\text { Kalmak-Kyrchyn } \\
\left(\mathrm{KK}_{2}\right)\end{array}$ & Sunflower & 1615 & $\begin{array}{l}41^{\circ} 07^{\prime} 06.54^{\prime \prime} \mathrm{N} \\
73^{\circ} 29^{\prime} 58.11^{\prime \prime} \mathrm{E}\end{array}$ & Northeast & 0.5 & Alfisol & Brown \\
\hline
\end{tabular}

${ }^{\mathrm{a}}$ Details regarding vegetation types are provided in material and methods.

(Amygdalus communis L.), plum (Prunus domestica L.), cherry plum (Prunus divaricata L.), Turkestanic hawthorn (Crataegus turkestanica A. Pojarn), Turkestanic maple (Acer turkestanicum Pach.), and white poplar (Populus alba L.). The understory is dominated by Impatiens parviflora, Viola isopetala, Geum urbanum, and Brachypodium silvaticum.

A second land use group represented grassland sites commonly used as open pasture areas primarily for cattle, but horses and sheep can also be present on the landscape (Figures 2(d)-2(e)). An elevation gradient was identified where three profiles were characterized and sampled: a Dark Sierozem (Inceptisol) profile at $930 \mathrm{~m}$ elevation, a Brown soil (Alfisol) at $1630 \mathrm{~m}$, and a Meadow-steppe (Mollisol) profile at $1940 \mathrm{~m}$ (Table 1). The flora along this gradient contained a wide diversity of grass species including: Artemisia vulgaris, Trifolium pratense, Poa pratensis, Thalictrum minus, Origanum vulgare, Rumex paulsenianus, Achillea bieberschteinii, Plantago lanceolata, Taraxacum alpigenum, Vicia angustifolia, Eremurus fuscus, Euphorbia alatavica, Exochorda tianschanica, and Inula macrophylla.

A third land use group represented long-term cultivated sites either under maize (Zea mays), cotton (Gossypium hirsutum), or sunflower (Helianthus annuus) for at least three consecutive years prior to sampling (Table 1; Figure 2(f)). The cotton and maize sites (furrow irrigated) were classified as Sierozems (Inceptisols) and located in the foothills at an elevation of $732 \mathrm{~m}$ and $833 \mathrm{~m}$, respectively. The sunflower site under a Brown soil (Alfisol) was not irrigated and was at an elevation of $1615 \mathrm{~m}$.

2.3. Soil Sampling and Analyses. The soil samples were collected by genetic horizons within each profile, air dried, passed through a $2-\mathrm{mm}$ sieve, and stored in cloth bags for subsequent analyses. Soil texture was determined by a rapid method as described by Kettler et al. [19]. Soil $\mathrm{pH}$ was measured from a 1:2 (soil: water) mixture using a combination glass electrode. Soil organic matter was determined by the weight loss on ignition method. Briefly, soil samples were oven-dried at $105^{\circ} \mathrm{C}$ overnight, cooled in a desiccator, and weighed. The samples were then ignited at $400^{\circ} \mathrm{C}$ for hours in a muffle furnace. After ignition, samples were transferred to a desiccator until it cooled and again weighted. The loss on ignition (LOI) was calculated using the following formula:

$$
\mathrm{LOI}=\left[\left(W_{1}-W_{2}\right) / W_{1}\right] \times 100
$$

where $W_{1}=$ oven-dry soil weight $(\mathrm{g})$ dried at $105^{\circ} \mathrm{C}$ and $W_{2}=$ soil weight after ignition at $400^{\circ} \mathrm{C}$. SOM was then estimated according to the equation: $\% \mathrm{SOM}=(\% \mathrm{LOI} *$ $0.7)-0.23$ as recommended in the Cornell Soil Health Assessment Training Manual [20]. Total N was determined by dry combustion using a Carlo Erba 1500 NA (Milan, Italy).

The enzyme activities, $\beta$-glucosidase, $\beta$-glucosaminidase, acid and alkaline phosphomonoesterase, phosphodiesterase, and arylsulfatase, were assayed using $0.5 \mathrm{~g}$ of air-dried soil with the appropriate assay conditions (i.e., incubated for $1 \mathrm{~h}$ at $37^{\circ} \mathrm{C}$ at their optimal $\mathrm{pH}$ and substrate final concentration) as described by Tabatabai [21]. $\beta$-glucosaminidase activity was determined similarly as described by Parham and Deng [22]. The enzyme activities were assayed in duplicate with one control, to which substrate was added after incubation (product of all reactions is $\mathrm{PN}=p$-nitrophenol). A summary of the assay conditions, reactions, and role of these enzymes in soil metabolic functioning is provided in Table 2. 
TABLE 2: Conditions for assay of soil enzyme activities and their role in soil biogeochemical functioning.

\begin{tabular}{|c|c|c|c|c|c|}
\hline \multirow[t]{2}{*}{ Class/EC number } & \multirow[t]{2}{*}{ Recommended name } & \multirow[t]{2}{*}{ Role in soil function } & \multicolumn{3}{|c|}{ Assay conditions } \\
\hline & & & Reaction & Substrate & Optimum pH \\
\hline \multicolumn{6}{|l|}{ C cycling } \\
\hline 3.2 .1 .21 & $\beta$-Glucosidase & $\begin{array}{l}\text { Cellulose degradation, } \\
\text { produces glucose needed } \\
\text { by plants and } \\
\text { microorganisms }\end{array}$ & $\begin{array}{l}\text { Glucoside- } \mathrm{R}+\mathrm{H}_{2} \mathrm{O} \rightarrow \\
\text { Glucose }+\mathrm{R}-\mathrm{OH}\end{array}$ & $\begin{array}{l}p \text {-Nitrophenyl- } \beta \text {-D- } \\
\text { glucopyranoside } \\
(10 \mathrm{mM})\end{array}$ & 6 \\
\hline \multicolumn{6}{|l|}{$\mathrm{C}$ and $\mathrm{N}$ cycling } \\
\hline 3.2 .1 .30 & $\beta$-Glucosaminidase & $\begin{array}{l}\text { Chitin degradation, } \\
\text { produces amino sugars, } \\
\text { one of the major sources } \\
\text { of mineralizable } \mathrm{N}\end{array}$ & $\begin{array}{c}\text { R-N-acetyl- } \beta \text {-D } \\
\text { glucosaminide } \rightarrow \text { R-OH }+ \\
\mathrm{N} \text {-acetyl- } \beta \text {-D- } \\
\text { glucosaminide }\end{array}$ & $\begin{array}{l}p \text {-Nitrophenyl-N- } \\
\text { acetyl- } \beta \text {-D- } \\
\text { glucosaminide } \\
(10 \mathrm{mM})\end{array}$ & 5.5 \\
\hline \multicolumn{6}{|l|}{ P cycling } \\
\hline 3.1 .3 .2 & Acid Phosphatase & $\begin{array}{l}\text { Produces plant available } \\
\text { phosphates, predominant } \\
\text { in acid soils }\end{array}$ & $\begin{array}{l}\mathrm{RNa}_{2} \mathrm{PO}_{4}+\mathrm{H}_{2} \mathrm{O} \rightarrow \\
\mathrm{R}-\mathrm{OH}+\mathrm{Na}_{2} \mathrm{HPO}_{4}\end{array}$ & $\begin{array}{l}\text { p-Nitrophenyl- } \\
\text { phosphate } \\
(10 \mathrm{mM})\end{array}$ & 6.5 \\
\hline 3.1 .3 .1 & Alkaline Phosphatase & $\begin{array}{l}\text { Produces plant available } \\
\text { phosphates, predominant } \\
\text { in alkaline soils }\end{array}$ & $\begin{array}{l}\mathrm{RNa}_{2} \mathrm{PO}_{4}+\mathrm{H}_{2} \mathrm{O} \rightarrow \\
\mathrm{R}-\mathrm{OH}+\mathrm{Na}_{2} \mathrm{HPO}_{4}\end{array}$ & $\begin{array}{c}\text { p-Nitrophenyl- } \\
\text { phosphate }(10 \mathrm{mM})\end{array}$ & 6.5 \\
\hline 3.1.4.1 & Phosphodiesterase & $\begin{array}{c}\text { Produced from plants, } \\
\text { animals, and } \\
\text { microorganisms }\end{array}$ & $\begin{array}{c}\mathrm{RNa}_{2} 2 \mathrm{PO}_{4}+\mathrm{H}_{2} \mathrm{O} \rightarrow \\
\mathrm{RNa}_{2} \mathrm{PO}_{4}+\mathrm{R}-\mathrm{OH}\end{array}$ & $\begin{array}{l}\text { bis-p-nitrophenyl } \\
\text { phosphate (10 mM) }\end{array}$ & 8 \\
\hline \multicolumn{6}{|l|}{ S cycling } \\
\hline 3.1.6.1 & Arylsulfatase & $\begin{array}{l}\text { Produces plant available } \\
\text { sulfates }\end{array}$ & $\begin{array}{c}\text { Phenol sulfate }+\mathrm{H}_{2} \mathrm{O} \rightarrow \\
\text { phenol }+ \text { sulfate }\end{array}$ & $\begin{array}{c}p \text {-Nitrophenyl-sulfate } \\
(10 \mathrm{mM})\end{array}$ & 5.8 \\
\hline
\end{tabular}

2.4. Data Calculations. As a survey, our purpose was to establish ranges of commonly used soil properties important for nutrient cycling and productivity among the three land use groups (pasture, forest, and cultivated) within the Kukart watershed. Enzymes were grouped into C-cycling and P- and $\mathrm{S}$-cycling groups using three-dimensional plots to determine if patterns among land use groups existed. In order to compare surface soils $(0-15 \mathrm{~cm})$, the top two soil depths were summed for the three forest sites and two of the three pasture sites. The remaining sites were already sampled at this depth (except for one of the cultivated sites where the first soil horizon was taken from 0 to $34 \mathrm{~cm}$ depth).

\section{Results and Discussion}

3.1. Soil Physical and Chemical Characterization of the Nine Soil Profiles. The texture within the top $57 \mathrm{~cm}$ of soil depth from the Kukart watershed was generally in the loam family (i.e., silt loams, silty clay loam, clay loams, etc.) and ranged in clay content from $6 \%$ to $39 \%$ (Table 3). In general, soil chemical properties were influenced by soil order. The Sierozem (Inceptisols) soils had the highest $\mathrm{pH}$ values and contained the lowest SOM and TN contents compared to the Brown (Alfisols), Black-brown, and Meadow-steppe soils (Mollisols). Soil pH values from Brown (Alfisols), Blackbrown and Meadow-steppe soils (Mollisols) ranged from 7.0 to 7.7 and values of the Sierozems (Inceptisols) ranged from 7.9 to 8.2 within the first two soil depths.
The two Brown and Black-brown (Mollisol) profiles from the nut-fruit forested sites $\left(\mathrm{KA}_{1}\right.$ and $\left.\mathrm{KA}_{2}\right)$ contained higher SOM levels (i.e., $12-16 \%$ from the Oe and $9-12 \%$ from the A1 horizons) compared to all other profiles $(<7.6 \%$ in the A horizons), including the other forest profile, which was a Sierozem (Inceptisol) under pistachio $\left(\mathrm{Su}_{1}\right)$. Additionally, these two forested sites had higher levels of SOM at depth compared to the other land use sites. For example, SOM was $2.65 \%$ within $48 \mathrm{~cm}$ depth at the $\mathrm{KA}_{1}$ site and $5.51 \%$ within $57 \mathrm{~cm}$ depth at the $\mathrm{KA}_{2}$ site. The levels of SOM found at greater than $1 \mathrm{~m}$ depth were comparable to the surface horizons of the cultivated Sierozems indicating the importance of vegetation-land use interactions in supporting SOM formation and stabilization [23]. Compared to other soil orders using the USDA system, the Inceptisols (Sierozems) of this watershed experience less precipitation and higher temperatures due to their geography (foothill position on the leeward side of the mountain range; 732-930 m). Among the Sierozems, the lowest SOM level was found in the cultivated cotton site, which is likely attributed to constraints on further soil development related to management interactions. Tillage, irrigation events, and quantity and quality of crop residues influences the balance between decomposition and accumulation of SOM. Of the cultivated sites studied, cotton produces lower residues compared to corn or sunflower [24].

3.2. Soil Enzyme Activities as Affected by Land Use and Soil Order. All enzyme activities generally decreased with increasing depth for the nine profiles (Table 4). Within the 


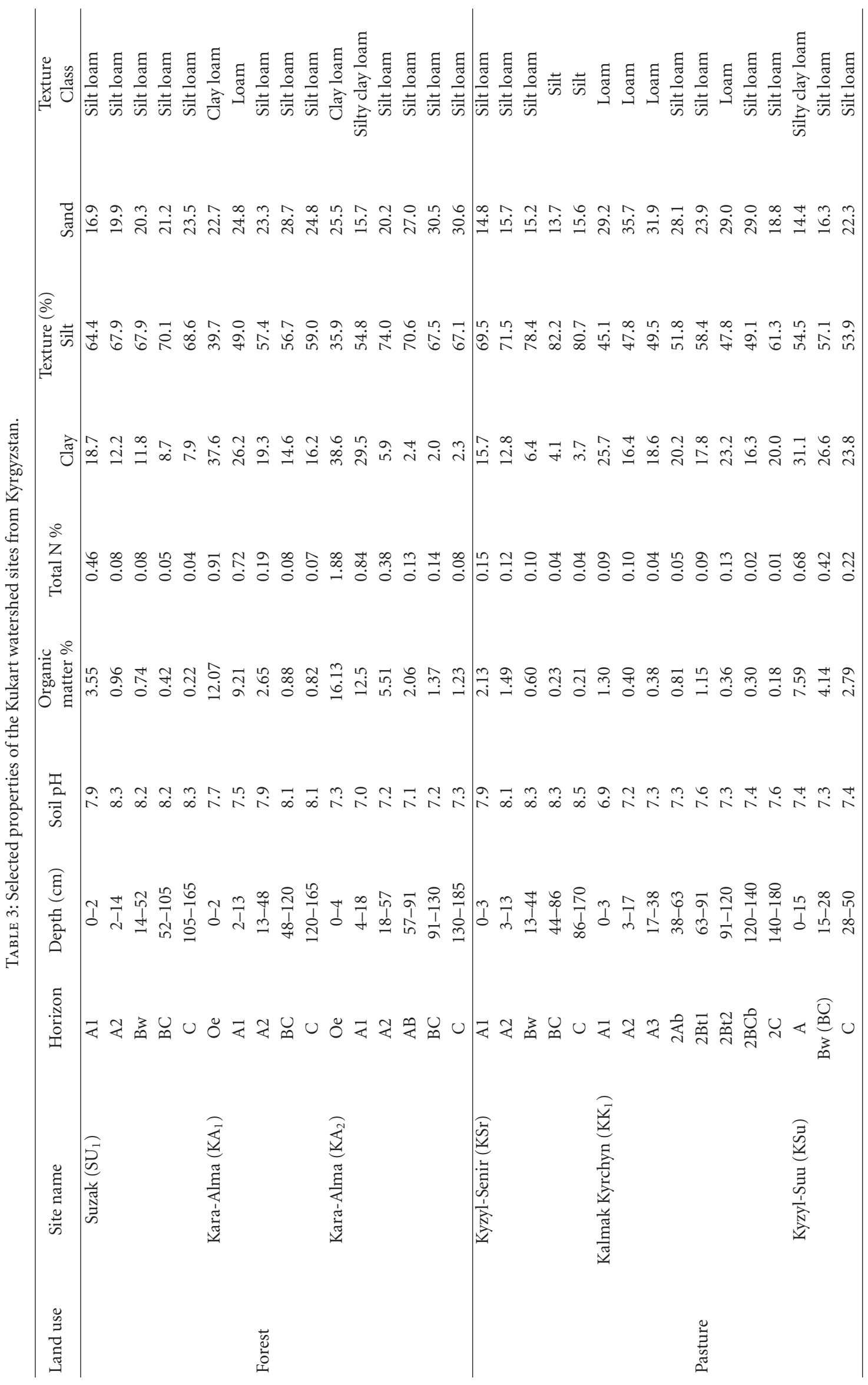




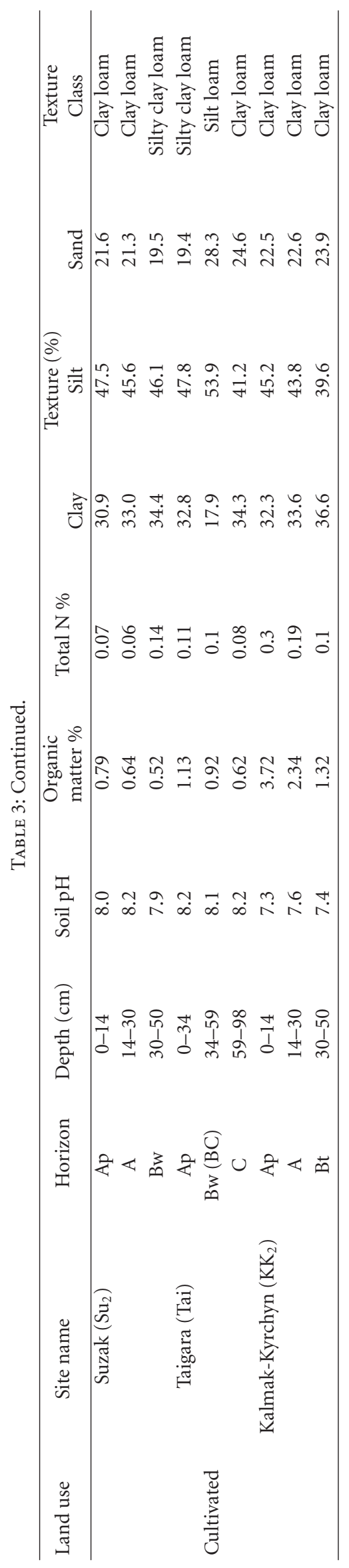


TABle 4: Enzyme activities ( $\mathrm{mg} \mathrm{PN} \mathrm{kg}^{-1}$ soil $\mathrm{h}^{-1}$ ) for the Kukart watershed sites of Kyrgyzstan ${ }^{\mathrm{a}}$.

\begin{tabular}{|c|c|c|c|c|c|c|c|c|}
\hline Land use & Site name & Depth $(\mathrm{cm})$ & $\begin{array}{c}\text { C cycling } \\
\beta \text {-Gluc }\end{array}$ & $\begin{array}{c}\text { C\&N cycling } \\
\beta \text {-Glucm }\end{array}$ & Acid phos & $\begin{array}{l}\text { P cycling } \\
\text { Alk phos }\end{array}$ & Phosphod & $\begin{array}{c}\text { S cycling } \\
\text { Aryl }\end{array}$ \\
\hline \multirow{16}{*}{ Forest } & \multirow{5}{*}{ Suzak $\left(\mathrm{SU}_{1}\right)$} & $0-2$ & 809.5 & 51.0 & 286.4 & 1021.5 & 560.9 & 115.4 \\
\hline & & $2-14$ & 38.3 & 8.8 & 22.9 & 67.3 & 17.6 & 5.3 \\
\hline & & $14-52$ & 16.0 & 10.6 & 17.9 & 59.0 & 33.7 & 8.7 \\
\hline & & $52-105$ & 7.6 & 7.5 & 12.0 & 36.0 & 26.0 & 8.1 \\
\hline & & $105-165$ & 5.3 & 5.6 & 2.8 & 6.6 & 8.0 & 1.7 \\
\hline & \multirow{5}{*}{ Kara-Alma $\left(\mathrm{KA}_{1}\right)$} & $0-2$ & 807.6 & 189.9 & 397.4 & 1441.5 & 746.2 & 498.9 \\
\hline & & $2-13$ & 1137.5 & 87.6 & 422.3 & 1033.0 & 742.1 & 393.3 \\
\hline & & $13-48$ & 135.1 & 14.7 & 114.7 & 244.6 & 222.1 & 114.3 \\
\hline & & $48-120$ & 27.1 & 4.0 & 29.8 & 76.5 & 43.8 & 33.5 \\
\hline & & $120-165$ & 19.3 & 2.1 & 26.0 & 57.5 & 85.2 & 19.6 \\
\hline & \multirow{6}{*}{ Kara-Alma $\left(\mathrm{KA}_{2}\right)$} & $0-4$ & 1235.9 & 298.5 & 712.7 & 1809.8 & 714.2 & 439.2 \\
\hline & & $4-18$ & 546.9 & 106.0 & 897.7 & 757.8 & 754.5 & 493.4 \\
\hline & & $18-57$ & 74.6 & 7.3 & 272.5 & 283.9 & 225.9 & 158.3 \\
\hline & & $57-91$ & 17.8 & 10.9 & 59.8 & 27.7 & 41.7 & 15.3 \\
\hline & & $91-130$ & 14.7 & 1.7 & 27.7 & 18.7 & 11.9 & 4.8 \\
\hline & & $130-185$ & 11.1 & 14.4 & 18.0 & 8.1 & 15.4 & 2.2 \\
\hline \multirow{16}{*}{ Pasture } & \multirow{5}{*}{ Kyzyl-Senir (KSr) } & $0-2$ & 428.7 & 43.3 & 176.2 & 594.3 & 303.6 & 81.3 \\
\hline & & $2-13$ & 209.3 & 34.5 & 81.8 & 285.5 & 177.7 & 34.9 \\
\hline & & $13-44$ & 25.7 & 11.2 & 21.0 & 72.7 & 53.4 & 18.4 \\
\hline & & $44-86$ & 7.4 & 6.2 & 2.4 & 20.5 & 11.5 & 3.5 \\
\hline & & $86-170$ & 2.0 & 2.9 & 1.3 & 9.6 & 5.3 & 2.4 \\
\hline & \multirow{7}{*}{ Kalmak Kyrchyn $\left(\mathrm{KK}_{1}\right)$} & $0-3$ & 323.6 & 45.7 & 146.8 & 276.0 & 258.9 & 77.1 \\
\hline & & $3-17$ & 25.4 & 7.7 & 24.3 & 54.6 & 40.1 & 9.8 \\
\hline & & $17-38$ & 16.4 & 6.8 & 24.9 & 32.2 & 21.0 & 11.7 \\
\hline & & $38-63$ & 33.9 & 9.2 & 35.5 & 79.2 & 49.1 & 21.4 \\
\hline & & $63-91$ & 64.6 & 13.7 & 70.9 & 109.0 & 79.1 & 48.5 \\
\hline & & $91-120$ & 11.1 & 6.9 & 21.1 & 29.9 & 16.4 & 6.5 \\
\hline & & $120-140$ & 3.8 & 4.5 & 19.6 & 34.3 & 16.2 & 7.9 \\
\hline & \multirow{4}{*}{ Kyzyl-Suu (KSu) } & $140-180$ & 1.4 & 3.7 & 10.6 & 2.0 & 2.7 & 1.4 \\
\hline & & $0-15$ & 513.6 & 58.2 & 978.3 & 431.3 & 467.4 & 381.2 \\
\hline & & $15-28$ & 77.5 & 25.6 & 371.7 & 340.9 & 212.7 & 160.8 \\
\hline & & $28-50$ & 24.5 & 8.6 & 134.0 & 174.0 & 107.9 & 56.6 \\
\hline \multirow{9}{*}{ Cultivated } & \multirow{3}{*}{ Suzak $\left(\mathrm{Su}_{2}\right)$} & $0-14$ & 69.8 & 11.9 & 228.9 & 162.1 & 83.4 & 23.4 \\
\hline & & $14-30$ & 22.8 & 5.8 & 42.7 & 84.5 & 53.9 & 14.0 \\
\hline & & $30-50$ & 3.3 & 4.2 & 31.5 & 80.4 & 67.7 & 9.1 \\
\hline & \multirow{3}{*}{ Taigara (Tai) } & $0-34$ & 79.7 & 9.8 & 63.5 & 166.4 & 107.5 & 28.2 \\
\hline & & $34-59$ & 29.6 & 11.8 & 37.5 & 83.8 & 55.2 & 14.7 \\
\hline & & 59-98 & 12.8 & 6.4 & 12.0 & 68.6 & 32.7 & 11.5 \\
\hline & \multirow{3}{*}{ Kalmak-Kyrchyn $\left(\mathrm{KK}_{2}\right)$} & $0-14$ & 202.2 & 30.6 & 141.1 & 337.6 & 214.6 & 101.0 \\
\hline & & $14-30$ & 60.9 & 18.8 & 135.9 & 212.5 & 127.8 & 85.3 \\
\hline & & $30-50$ & 18.0 & 6.7 & 36.3 & 104.6 & 46.3 & 23.1 \\
\hline
\end{tabular}

${ }^{a}$ PN: $p$-nitrophenol; $\beta$-Gluc: $\beta$-glucosidase; $\beta$-Glucm: $\beta$-glucosaminidase; Acid phos: acid phosphatase; Alk phos: alkaline phosphatase; Phosphod: phosphodiesterase; Aryl: arylsulfatase.

forest sites, the pistachio forest $\left(\mathrm{Su}_{1}\right)$ showed a substantial decrease from the $0-2 \mathrm{~cm}$ depth to the $2-14 \mathrm{~cm}$ in all enzymes compared to differences in similar depths for the two forest sites under nut-fruit forests $\left(\mathrm{KA}_{1}\right.$ and $\left.\mathrm{KA}_{2}\right)$. This observation is likely related to the lack of an $\mathrm{O}$ horizon in the
Sierozem (Inceptisol) of the $\mathrm{Su}_{1}$ site and further influenced by potential differences in litter chemistry and climate shifts between the low $\left(\mathrm{Su}_{1}\right)$ and high $\left(\mathrm{KA}_{1}\right.$ and $\left.\mathrm{KA}_{2}\right)$ elevation sites. The decrease of enzyme activities with depth can be mainly attributed to the mitigation of biological activity 


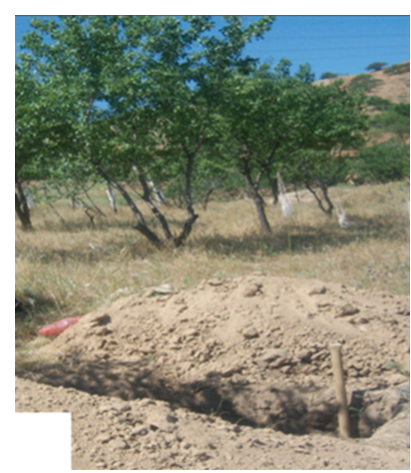

(a)

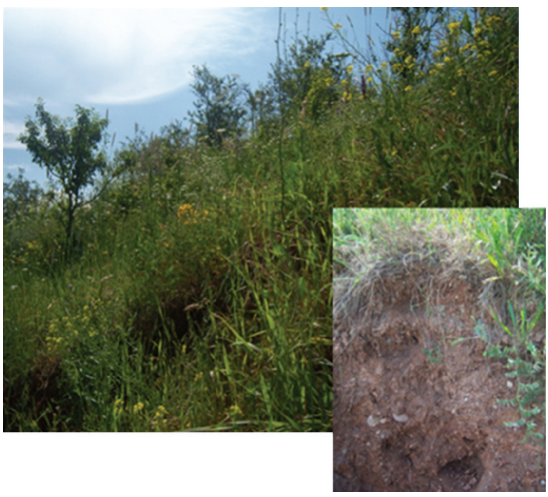

(d)

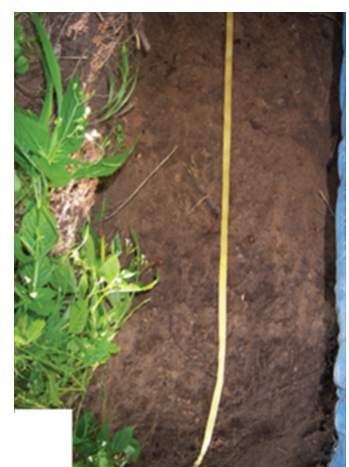

(b)

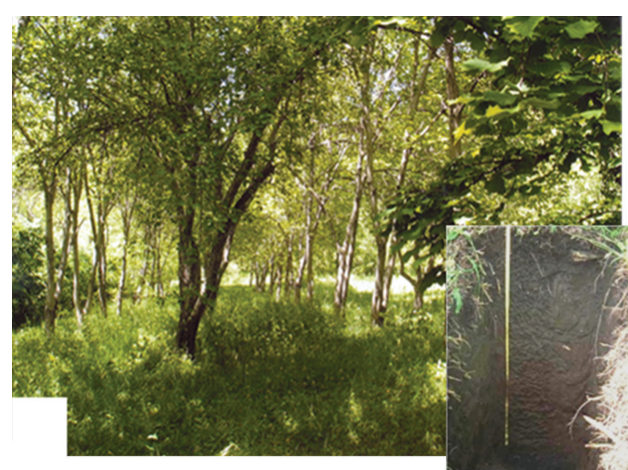

(c)

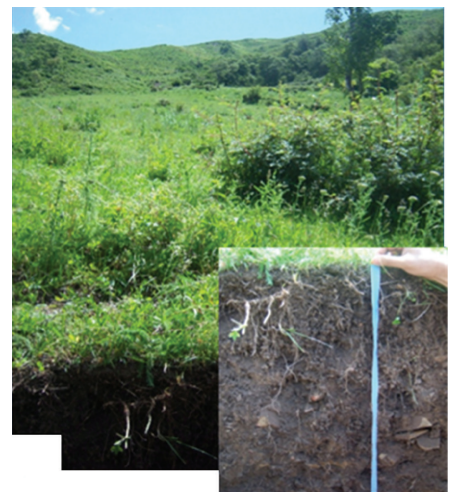

(e)

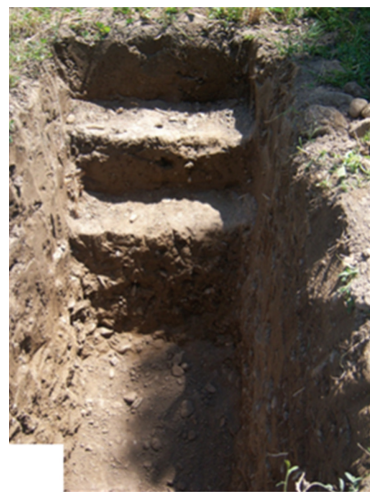

(f)

Figure 2: Representative landscape and soil profile pictures of the Kukart watershed including forest sites (a-c), pasture (d-e), and cultivated (f) land use. The forest sites included Pistachio plantation located at the Suzak $\left(\mathrm{Su}_{1}\right)$ site under a Sierozem (a) and two Walnut-fruit forests under a Brown soil (b) and a Black-brown soil (c) located at the Kara-Alma sites, $\mathrm{KA}_{1}$ and $\mathrm{KA}_{2}$, respectively. Two of the pasture sites are shown under a Brown soil $(\mathrm{d})$ in Kalmak Kyrchyn $\left(\mathrm{KK}_{1}\right)$ and a Meadow-steppe soil (e) in Kyzyl-Suu (KSu). The Maize cultivated profile at Taigara (Tai) under Sierozem is shown (f). Details regarding the sites are described in Table 1.

down the profile [25]. The decrease of enzyme activities and microbial biomass with soil depth has been noted in other studies [26, 27].

Enzymatic activities among land use groups within surface horizons $(0-18 \mathrm{~cm})$ typically decreased in the following order: forest > pasture > cultivated. Generally, enzyme activities are correlated to SOM content because litter plays a key role as a precursor for enzyme synthesis and in enzyme physical stabilization [21] but litter quality is also important. In general, forested sites, which tend to have higher lignin content, $\mathrm{C}: \mathrm{N}$ ratios, and lignin $: \mathrm{N}$ ratios, resulted in greater accumulation of SOM in comparison to pasture or cultivated lands [28]. The SOM does not tend to accumulate in cultivated sites because harvest removes biomass and tillage of the remaining residues accelerates breakdown of SOM.

The ranges of enzyme activities (e.g., alkaline phosphatase and $\beta$-glucosidase) found in the soil surface of the nine profiles from the Kukart watershed in Kyrgyzstan were much higher than values reported for other forest and grasslands, but similar to cultivated land in a review for soils across the world [29]. Soil $\beta$-glucosidase activity ranged from 848 to $1945 \mathrm{mg} \mathrm{PN} \mathrm{kg}^{-1}$ soil h $\mathrm{h}^{-1}$ in the forest (adding up both first depths to $\sim 15 \mathrm{~cm}$ ), 349 to $635 \mathrm{mg} \mathrm{PN} \mathrm{kg}^{-1}$ soil $\mathrm{h}^{-1}$ in the pasture (adding up both soil depths to $\sim 15 \mathrm{~cm}$ ), and 69.8 to $202 \mathrm{mgPN} \mathrm{kg}^{-1}$ soil $\mathrm{h}^{-1}(0-14$ or to $34 \mathrm{~cm})$ in the cultivated sites (Table 4). The ranges detected for this enzyme activity, which is important in $\mathrm{C}$ cycling, may suggest very distinct soil $\mathrm{C}$ substrates availability among these land uses. The forest sites showed more than two times higher values of this enzyme activity compared to the pasture sites and between 9 and 12 times higher compared to the cultivated sites. $\beta$-glucosaminidase activity is an enzyme involved in both $\mathrm{C}$ and $\mathrm{N}$ cycling and has been shown to be highly correlated with $\mathrm{N}$ mineralization [22]. Ranges for this enzyme followed a similar pattern as those shown for $\beta$-glucosidase: forest sites ranged from 59.7 to 405 (0$14 \mathrm{~cm})$, pasture from 53.4 to $77.8(0-17 \mathrm{~cm})$, and cultivated sites ranged from 9.8 to $30.6(0-34 \mathrm{~cm}) \mathrm{mg} \mathrm{PN} \mathrm{kg}^{-1}$ soil h$^{-1}$. In general, forested sites tend to support increased fungal biomass and more complex C sources (chitin) compared with pasture and cultivated profiles, which may explain the higher levels of $\beta$-glucosaminidase found in the forested sites compared with the other land uses. Although the Brown and Black-brown surface soils $(0-18 \mathrm{~cm})$ under forest had higher $\beta$-glucosaminidase and $\beta$-glucosidase activities than those under the pistachio forest $\left(\mathrm{Su}_{1}\right)$ in a Sierozem $(0-14 \mathrm{~cm})$, the pistachio Sierozem had higher levels of these enzymes than the two pastures under Brown and Meadow-steppe soils 


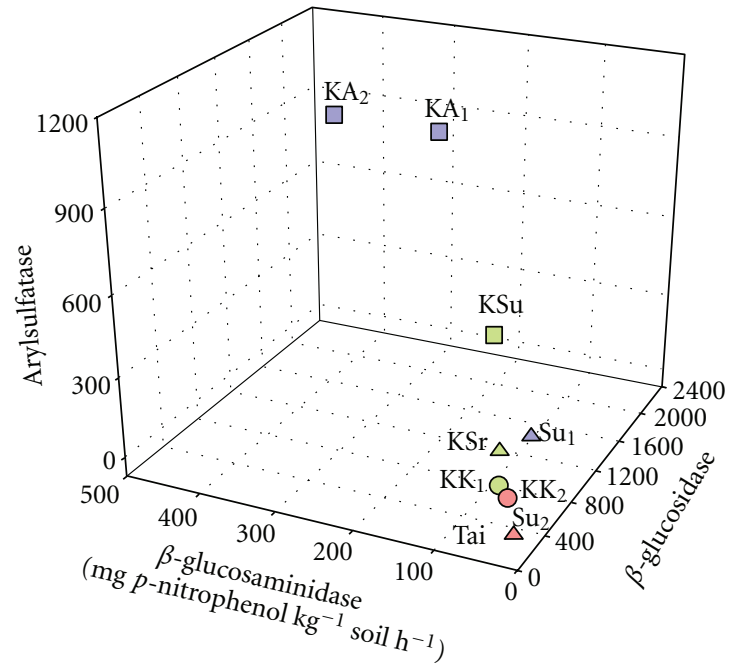

Symbols (soil order)

Square $=$ Mollisols

Circle $=$ Alfisols

Triangle $=$ Inceptisols

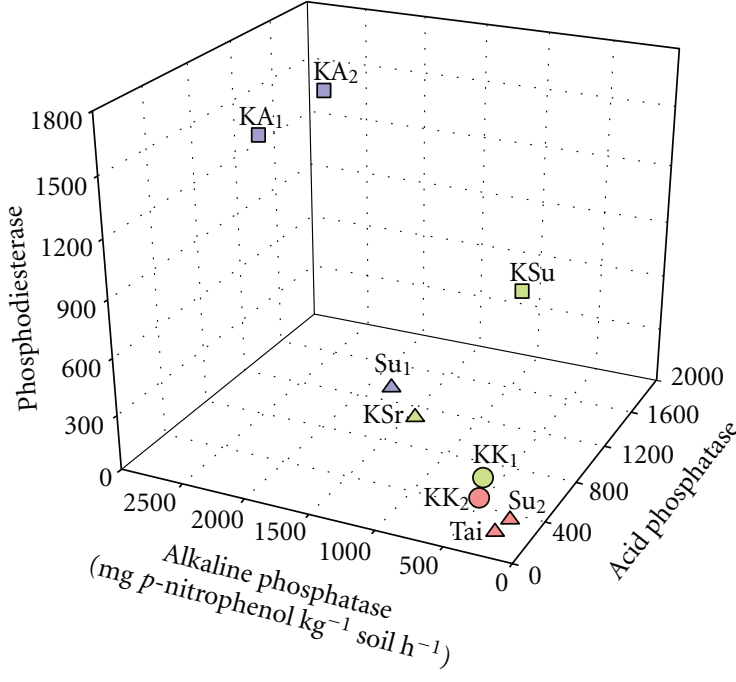

Color (land use)

Blue $=$ forest

Green $=$ pasture

Red $=$ cultivated

FIGURE 3: Three-dimensional plots showing three enzyme activities at a time under forest (blue), pasture (green), and cultivated (red). Soils were grouped according to taxonomy and are distinguished by squares (soils under Black-brown and Meadow-steppe or Mollisols), circles represent Brown soil (Alfisols) and triangles represent Sierozems (Inceptisols). The first two depths were summed for forest sites $\left(\mathrm{Su}_{1}\right.$, $\mathrm{KA}_{1}$, and $\left.\mathrm{KA}_{2}\right)$ and for two of the pasture sites $\left(\mathrm{KSr}, \mathrm{KK}_{1}\right)$. The third pasture site is abbreviated $\mathrm{KSu}$. The cultivated sites are abbreviated $\left(\mathrm{Su}_{2}\right.$, Tai, and $\mathrm{KK}_{2}$. Details regarding the sites are described in Table 1.

$\left(\mathrm{KK}_{1}\right.$ and $\left.\mathrm{KSu}\right)$. This indicates that land use and more likely, substrate quality of decomposing residues within each land use are strong drivers of metabolic potential rather than soil type or SOM content alone. Among the P and S cycling enzyme patterns, only phosphodiesterase activity showed a clear distinction between the three land uses. The activity of this enzyme ranged from 579 to 1488,299 to 481 , and 83.4 to $215 \mathrm{mg} \mathrm{PN} \mathrm{kg}^{-1}$ soil h$^{-1}$ for the forest, pasture, and cultivated sites, respectively.

Enzyme activity trends due to land use were present regardless of elevation, climate, and soil types although more subtle differences among soil types within a land use were observed. For example, among the forest sites, the Inceptisol site $\left(\mathrm{Su}_{1}\right.$, Sierozem $)$ had the lowest enzyme activities and SOM values and these values were comparable to the Inceptisol pasture site (KSr, Sierozem) (Figure 3). However, Inceptisols under cultivation showed the lowest levels of enzyme activities among this group of soils evaluated. A study by Acosta-Martínez et al., [30] in a tropical watershed found that the management practice influenced the forest and pasture land uses tended to increase the enzyme activities in the Inceptisols compared to the other soil orders. The authors suggested that nutrient cycling as monitored by enzyme activities in Inceptisols under agriculture could be increased with adoption of conservation practices to levels comparable to other soil orders under pasture or forest. In general, Mollisols by definition contain greater SOM content than Inceptisols, which is related to processes that occurred during soil formation. Although SOM was strongly correlated with enzyme activity $(r>0.85)$, we did not find significant correlations between enzyme activities and inherit soil properties such as $\mathrm{pH}$ or clay content as has been shown in other studies $[26,31]$.

\section{Conclusion}

This study provided the first soil survey on the characterization of key soil chemical, physical, and biochemical properties of nine soil profiles in the Kukart watershed, Kyrgyzstan. Our results demonstrated the important interactive forces between inherent soil properties (e.g., $\mathrm{pH}$ and texture) and land management on dynamic soil properties (SOM and enzyme activities) important for soil quality and ecosystem functioning. The significant reductions in measured soil enzyme activities involved in $\mathrm{C}, \mathrm{N}, \mathrm{P}$, and $\mathrm{S}$ nutrient transformations under cultivation compared to pasture and forest ecosystems and lower values under Inceptisols can serve as soil quality indicators for land use decisions in the watershed. This study serves as a baseline for further soil classification efforts within the Kukart watershed and similar watersheds within Kyrgyzstan.

\section{Disclosure}

The use of trade, firm, or corporation names in this publication is for the information and convenience of the 
reader. Such use does not constitute an official endorsement or approval by the United States Department of Agriculture or the Agricultural Research Service of any product or service to the exclusion of others that may be suitable. The USDA is an equal opportunity provider and employer.

\section{Acknowledgments}

This study was partially supported by the Fulbright Scholar Program of USA. The first author is grateful for the opportunity given by Dr. Richard Zartman to work in the Department of Plant and Soil Science at Texas Tech University. Additionally, the authors thank Dr. Ewald Brauner and his staff from University of Natural Resources and life Sciences of Vienna, Austria for soil total nitrogen analyses. This work is dedicated to the memory of Dr. W. Hudnall, who died on July 1, 2012. Wayne contributed to the detailed classification of these soil profiles in terms of the morphology and genesis of the soil horizons due to his vast years of experience in this area. He was the B. L. Allen Endowed Chair for Pedology in the Department of Plant and Soil Science at Texas Tech University. His expertise will be greatly missed, but his devotion to soil conservation efforts will continue to inspire many generations.

\section{References}

[1] W. A. Dick and M. A. Tabatabai, "Potential uses of soil enzymes," in Soil Microbial Ecology: Applications in Agricultural and Environmental Management, F. B. Metting, Ed., pp. 95-127, Marcel Dekker, New York, NY, USA, 1992.

[2] E. Kandeler, C. Kampichler, and O. Horak, "Influence of heavy metals on the functional diversity of soil microbial communities," Biology and Fertility of Soils, vol. 23, no. 3, pp. 299-306, 1996.

[3] C. Trasar-Cepeda, M. C. Leirós, and F. Gil-Sotres, "Biochemical properties of acid soils under climax vegetation (Atlantic oakwood) in an area of the European temperate-humid zone (Galicia, NW Spain): specific parameters," Soil Biology and Biochemistry, vol. 32, no. 6, pp. 747-755, 2000.

[4] V. Acosta Martínez, S. E. Dowd, C. Bell et al., "Microbial community composition as affected by dryland cropping systems and tillage in a semiarid sandy soil," Diversity, vol. 2, pp. 910-931, 2010.

[5] E. Kandeler, D. Tscherko, and H. Spiegel, "Long-term monitoring of microbial biomass, $\mathrm{N}$ mineralisation and enzyme activities of a chernozem under different tillage management," Biology and Fertility of Soils, vol. 28, no. 4, pp. 343-351, 1999.

[6] V. Acosta-Martínez and M. A. Tabatabai, "Tillage and residue management effects on arylamidase activity in soils," Biology and Fertility of Soils, vol. 34, no. 1, pp. 21-24, 2001.

[7] A. K. Bandick and R. P. Dick, "Field management effects on soil enzyme activities," Soil Biology and Biochemistry, vol. 31, no. 11, pp. 1471-1479, 1999.

[8] S. Klose, J. M. Moore, and M. A. Tabatabai, "Arylsulfatase activity of microbial biomass in soils as affected by cropping systems," Biology and Fertility of Soils, vol. 29, no. 1, pp. 46-54, 1999.

[9] E. L. Ndiaye, J. M. Sandeno, D. McGrath, and R. P. Dick, "Integrative biological indicators for detecting change in soil quality," American Journal of Alternative Agriculture, vol. 15, no. 1, pp. 26-36, 2000.
[10] M. L. Staben, D. F. Bezdicek, J. L. Smith, and M. F. Fauci, "Assessment of soil quality in conservation reserve program and wheat-fallow soils," Soil Science Society of America Journal, vol. 61, no. 1, pp. 124-130, 1997.

[11] V. L. Gewin, A. C. Kennedy, R. Veseth, and B. C. Miller, "Soil quality changes in eastern Washington with Conservation Reserve Program (CRP) take-out," Journal of Soil and Water Conservation, vol. 54, no. 1, pp. 432-438, 1999.

[12] V. Acosta-Martínez, T. M. Zobeck, T. E. Gill, and A. C. Kennedy, "Enzyme activities and microbial community structure in semiarid agricultural soils," Biology and Fertility of Soils, vol. 38, no. 4, pp. 216-227, 2003.

[13] Food Agriculture Organization of the United Nations, "Kyrgyzstan profile," http://www.fao.org/countries/55528/en/kgz/.

[14] G. E. Hemery, "Walnut seed-collecting expedition to Kyrgyzstan in Central Asia," Quarterly Journal of Forestry, vol. 92, pp. 153-157, 1998.

[15] M. Kononova, "Organic matter of soils, its nature, properties and methods of study," Academy Nauk of SSSR, Moskov, pp. 145-153, 1963 (Russian).

[16] G. Buherer, Microflora of Main Soils of Kyrgyzstan, Nauka, Moscow, Russia, 1966.

[17] A. Mamytov, G. I. Roichenko, and G. Buherer, Group Composition of Humus of Main Soil Types of Kyrgyz Republic, Ilim, Frunze, Kyrgyzstan, 1971.

[18] G. I. Roichenko, The Soils of South Kyrgyzstan, Academy Nauk of Kyrgyz SSR, Frunze, Kyrgyzstan, 1960.

[19] T. A. Kettler, J. W. Doran, and T. L. Gilbert, "Simplified method for soil particle-size determination to accompany soilquality analyses," Soil Science Society of America Journal, vol. 65, no. 3, pp. 849-852, 2001.

[20] B. K. Gugino, O. J. Idowu, R. R. Schindelbeck et al., "Cornell soil health assessment training manual," Edition 2.0, Cornell University, Geneva, NY, USA, 2009.

[21] M. A. Tabatabai, "Soil enzymes," in Methods of Soil Analysis: Microbiological and Biochemical Properties, R. W. Weaver, J. S. Angle, and P. S. Bottomley, Eds., vol. 5 of SSSA Book Series, Part 2, pp. 775-833, SSSA, Madison, Wis, USA, 1994.

[22] J. A. Parham and S. P. Deng, "Detection, quantification and characterization of $\beta$-glucosaminidase activity in soil," Soil Biology and Biochemistry, vol. 32, no. 8-9, pp. 1183-1190, 2000.

[23] V. Acosta-Martínez, D. Acosta-Mercado, D. SotomayorRamírez, and L. Cruz-Rodríguez, "Microbial communities and enzymatic activities under different management in semiarid soils," Applied Soil Ecology, vol. 38, no. 3, pp. 249260, 2008.

[24] L. M. Zibilske and L. A. Materon, "Biochemical properties of decomposing cotton and corn stem and root residues," Soil Science Society of America Journal, vol. 69, no. 2, pp. 378-386, 2005.

[25] M. F. E. Lavahun, R. G. Joergensen, and B. Meyer, "Activity and biomass of soil microorganisms at different depths," Biology and Fertility of Soils, vol. 23, no. 1, pp. 38-42, 1996.

[26] R. Kizilkaya and O. DengIz, "Variation of land use and land cover effects on some soil physico-chemical characteristics and soil enzyme activity," Zemdirbyste, vol. 97, no. 2, pp. 15-24, 2010.

[27] J. Kazimierz, "The enzyme activity of the forest soils of Southern Poland as a measure of soil quality," Electronic Journal of Polish Agricultural Universities, vol. 14, pp. 1-13, 2011.

[28] J. M. Melillo, J. D. Aber, A. E. Linkins, A. Ricca, B. Fry, and K. J. Nadelhoffer, "Carbon and nitrogen dynamics along the decay 
continuum: plant litter to soil organic matter," Plant and Soil, vol. 115, no. 2, pp. 189-198, 1989.

[29] C. Emmerling, M. Schloter, A. Hartmann, and E. Kandeler, "Functional diversity of soil organisms-a review of recent research activities in Germany," Journal of Plant Nutrition and Soil Science, vol. 165, pp. 408-420, 2002.

[30] V. Acosta-Martínez, D. Acosta-Mercado, D. SotomayorRamírez, and L. Cruz-Rodríguez, "Microbial communities and enzymatic activities under different management in semiarid soils," Applied Soil Ecology, vol. 38, no. 3, pp. 249260, 2008.

[31] F. Eivazi and M. A. Tabatabai, "Phosphatases in soils," Soil Biology and Biochemistry, vol. 9, no. 3, pp. 167-172, 1977. 

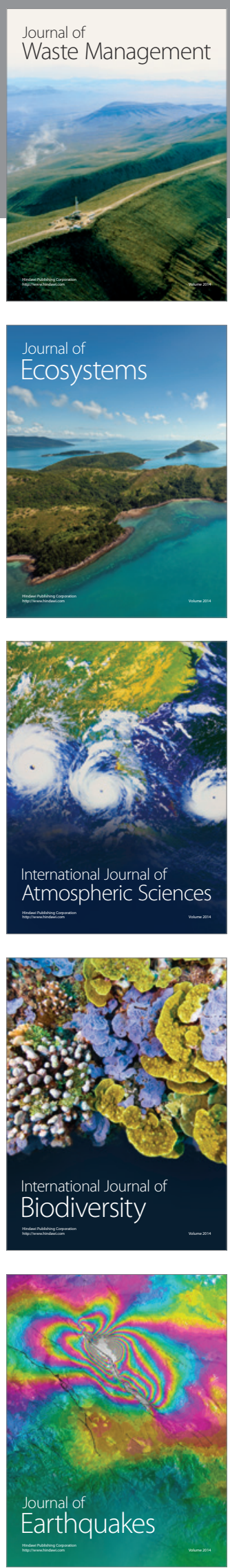
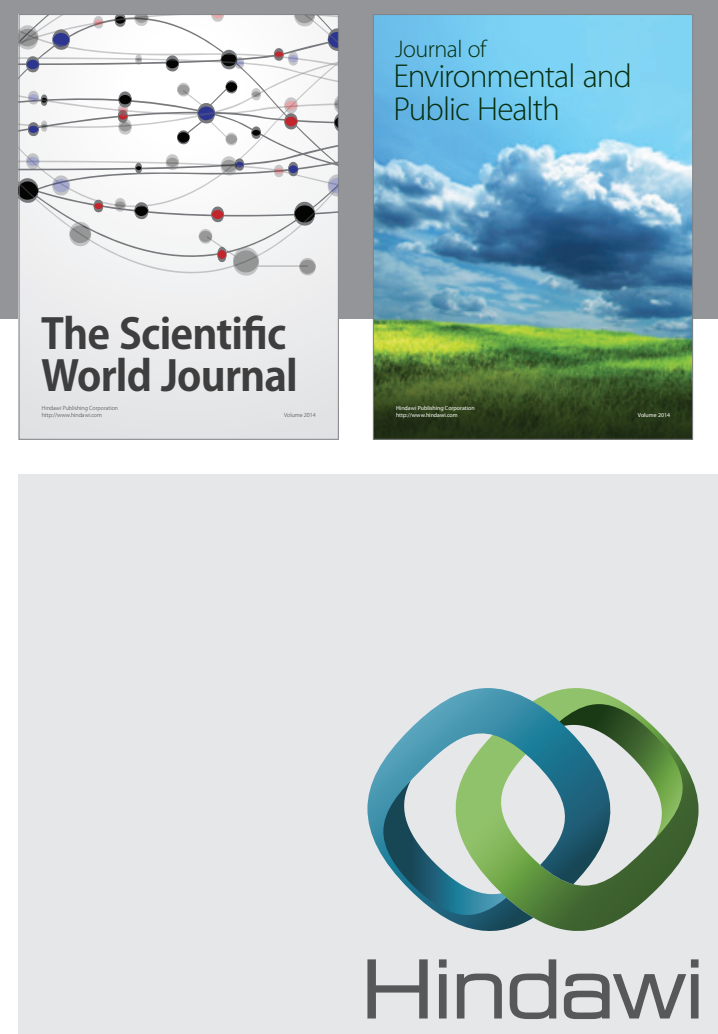

Submit your manuscripts at

http://www.hindawi.com
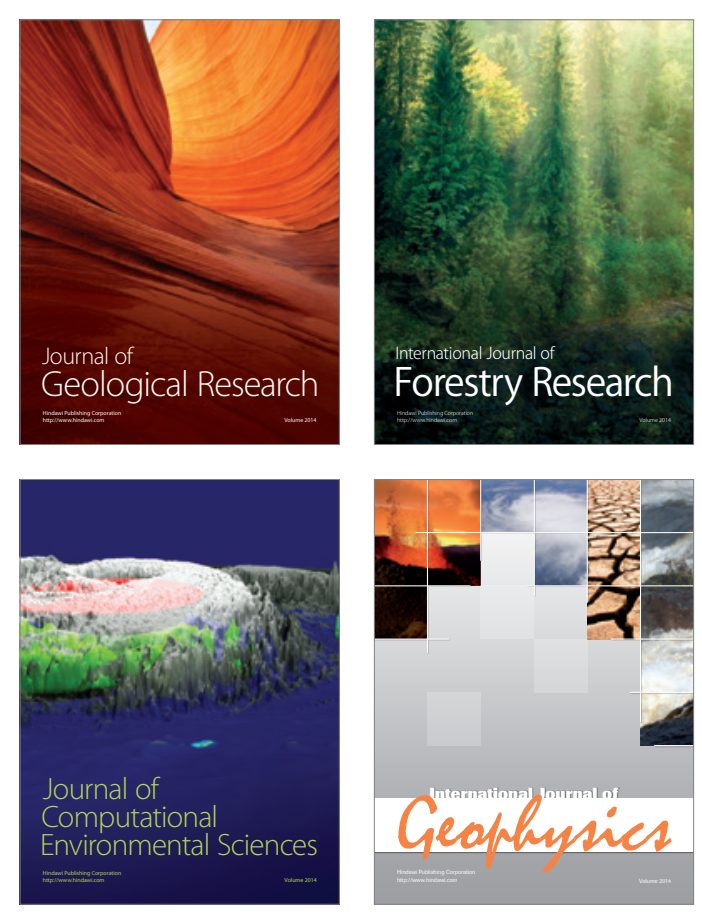
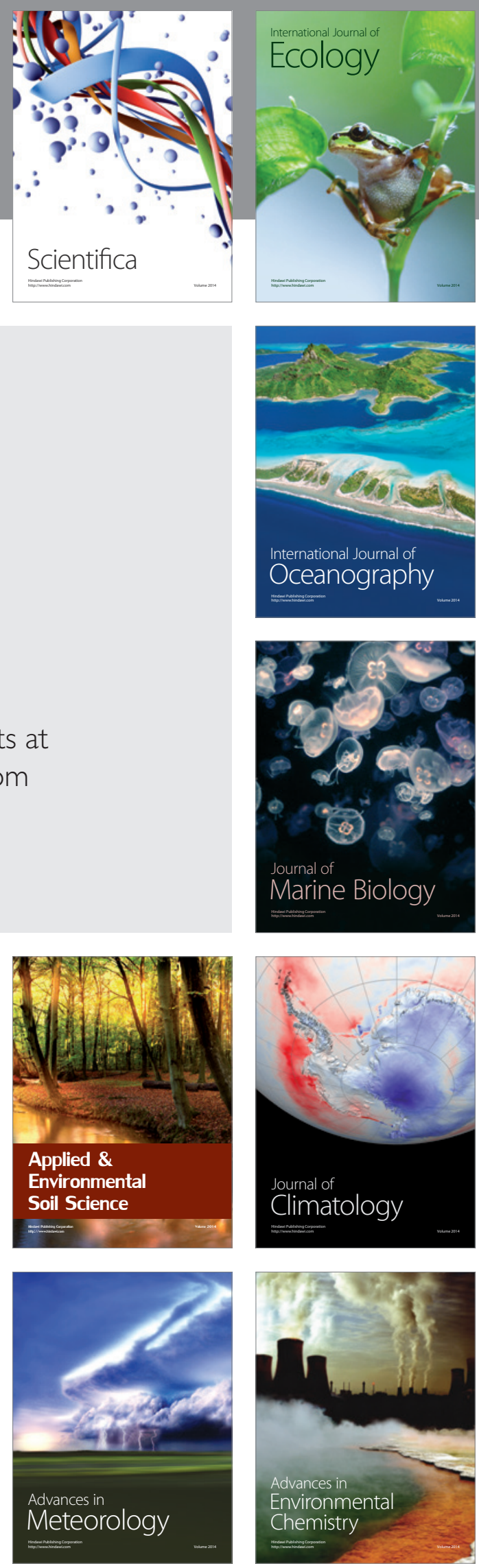